Avrupa Bilim ve Teknoloji Dergisi

Özel Sayl, 34, S. 336-343, Mart 2022

(C) Telif hakkı EJOSAT'a aittir

Araștırma Makalesi
European Journal of Science and Technology

Special Issue 34, pp. 336-343, March 2022

Copyright (C) 2022 EJOSAT

$\underline{\text { Research Article }}$

\title{
Kentsel Dönüşümde İş Sağlığı ve Güvenliği
}

\author{
Abdullah Gündoğay ${ }^{*}$ \\ 1* Süleyman Demirel Üniversitesi, Mühendislik Fakültesi, İnşaat Mühendisliği Bölümü, Isparta, Türkiye, (ORCID: 0000-0002-5355-9014), \\ abdullahgundogay@sdu.edu.tr
}

(2nd International Conference on Applied Engineering and Natural Sciences ICAENS 2022, March 10-13, 2022)

(DOI: $10.31590 /$ ejosat.1082160)

ATIF/REFERENCE: Gündoğay, A. (2022). Kentsel Dönüşümde İş Sağlığı ve Güvenliği. Avrupa Bilim ve Teknoloji Dergisi, (34), $336-343$.

\section{$\ddot{O} \mathbf{z}$}

Ülkemizdeki binaların çoğunluğu betonarme binalardan meydana gelmektedir. Bu binaların çok büyük bir kısmı mühendislik hizmeti ve deprem etkisi dikkate alınmadan inşa edildiğinden dolayı kendisinden beklenen deprem performansını sağlayamamaktadır. Bu sebeple depremde meydana gelebilecek can ve mal kayıplarını önlemek ve en aza indirmek amacıyla yapılması gerekenlerin en başında depreme dayanıklı binalar inşa etmek, deprem güvenliği yetersiz olan binaları depreme dayanıklı hale getirmek veya yıkım işlemini gerçekleştirmektir. Bundan dolayı binaların deprem güvenliğinin incelenmesi ve gerekli görülenlerin yıkılarak yenilerinin inşa edilmesi önemli konulardan biri haline gelmektedir. Ülkemizdeki yapı stoku düşünüldüğünde yıkılacak olan binalarda gerekli olan iş sağlığı ve güvenliği önlemlerinin alınması ve uygulanması da büyük önem arz etmektedir. Bu çalışma kapsamında Isparta ilinde bulunan 6 adet betonarme konut binasının deprem güvenliği Türkiye Bina Deprem Yönetmeliği’ne (TBDY, 2018) göre incelenerek belirlenmiş ve ilgili yönetmelikte sağlaması gereken deprem performans seviyesini sağlamadığı görülmüsstür. Bu yüzden kentsel dönüşüm kapsamında yıkılması gerektiğine karar verilmiştir. Binaların yıkım işlemleri aşamasında ülkemizde kullanılmakta olan mevcut standart ve yönetmelikler, iş sağlığı ve güvenliği açısından ele alınarak incelenmiştir. Yapılan incelemeler sonucunda iş sağılığı ve güvenliği açısından ülkemizde kullanılmakta olan mevcut standart ve yönetmeliklerin günümüz şartlarına göre revize edilerek daha kapsamlı hale getirilmesi gerektiği görülmüştür. Bilinçsiz yıkım işlemlerinin ve iş kazalarının önüne geçilebilmesi için gerekli denetim ve kontrollerin yapılması gerektiği görülmüştür.

Anahtar Kelimeler: Betonarme Bina, Deprem Güvenliği, İş Sağlığı ve Güvenliği, Kentsel Dönüşüm, Yıkım İşleri.

\section{Occupational Health and Safety in Urban Transformation}

\begin{abstract}
Most of the buildings in our country are reinforced concrete buildings. Most of these buildings can not provide the expected earthquake performance since they were built without considering the engineering service and the earthquake effect. Hence, in order to prevent and minimize the loss of life and property that may occur in an earthquake, the first thing to do is to build earthquake resistant buildings, to make buildings earthquake resistant which have insufficient earthquake safety or to carry out the demolition process. Therefore, investigating the earthquake safety of the buildings, demolishing the necessary ones and constructing new ones becomes one of the vital issues. Considering the building stock in our country, it is of great importance to take and implement the necessary occupational health and safety measures in the buildings to be demolished. Within the scope of this study, the earthquake safety of 6 reinforced concrete residential buildings in the province of Isparta was determined by examining according to the Turkish Building Earthquake Code (TBEC, 2018), and it was observed that it did not provide the earthquake performance level required to be provided in the relevant code. Therefore, it was decided that they should be demolished within the scope of urban transformation. The existing standards and regulations used in our country have been examined in terms of occupational health and safety during the demolition process of buildings. As a result of the investigations, it has been observed that the current standards and regulations used in our country in terms of occupational health and safety should be revised and made more comprehensive according to today's
\end{abstract}

* Sorumlu Yazar: abdullahgundogay@ sdu.edu.tr 
conditions. It has been observed that necessary inspections and controls should be carried out in order to prevent unconscious demolition processes and occupational accidents.

Keywords: Reinforced Concrete Building, Earthquake Safety, Occupational Health and Safety, Urban Transformation, Demolition Works.

\section{Giriş}

Dünya üzerinde büyük alanları etkileyerek can ve mal kayıplarına neden olan heyelan, sel, deprem, vb. doğal afetlerle ülkeler zaman zaman karşılaşmaktadır. Ülkemizin de bu doğal afetlerden maalesef etkilendiği olmuştur. Özellikle son 60 yılda ülkemizde oluşan doğal afetlerin neden olduğu yapısal hasarların dağılımı incelendiğinde depremlerin \%61, heyelanların $\% 15$, su baskınlarının \%14, kaya düşmelerinin $\% 5$, yangınların $\% 4$ ve çı̆̆ fırtına, vb. afetlerin ise \%1'ini oluşturduğu görülmüştür [1]. Buradan ülkemiz için en önemli etkenin deprem olduğu görülmektedir.

Geçmiş yıllarda meydana gelen depremler, gelecekte de ülkemizde depremlerin olacağının habercisidir. Günümüzde depremlerin hangi büyüklükte, nerede ve ne zaman olacağının bilinmesi ve olabilecek depremlerin önlenebilmesi maalesef mümkün olmamaktadır. Ancak depremde esnasında meydana gelebilecek olan can ve mal kayıplarının önlenebilmesi için yapılması gerekenlerin başında, mevcut binaların deprem güvenliği belirlenerek gerekli görülen tedbirlerin alınması ve depreme dayanıklı binaların inşa edilmesi olacaktır. Özellikle mevcut binaların deprem güvenliğinin incelendiği çalışmalarda gerekli olan deprem performansını sağlamadığı görülmüştür [2$6]$.

Ülkemizde geçmişte can ve mal kayıplarına neden olan birçok yıkıcı deprem meydana gelmiştir. Son 60 yıl içerisinde ülkemizde meydana gelmiş ve büyüklüğü 6.5 ve üzeri olan depremler Tablo 1'de verilmiştir. Bu depremler içerisinden özellikle 17 Ağustos 1999 tarihinde meydana gelen Gölcük (Kocaeli) depreminde 17480 kişi hayatını kaybetmiş ve 73342 bina hasar görmüştür [7]. Bu tarihten sonra inşaat sektöründe kullanılan yönetmelikler revize edilmeye başlanılmıştır. Bu kapsamda 2007 yılında Bayındırlık ve İskân Bakanlığı tarafından yeni yapılacak binaların deprem etkisi altında tasarımı ile mevcut binaların değerlendirilmesi ve güçlendirilmesi için Deprem Bölgelerinde Yapılacak Binalar Hakkında Yönetmelik (DBYBHY, 2007) [8] yayımlanmıştır. 2019 yılında ise DBYBHY (2007) yürürlükten kaldırılarak yerine daha kapsamlı ve ayrıntılı olarak hazırlanan Türkiye Bina Deprem Yönetmeliği (TBDY, 2018) [9] yürürlüğe girmiştir. Ayrıca TBDY (2018) ile birlikte eş zamanlı olarak Türkiye Deprem Tehlike Haritası da güncellenmiştir (Şekil 1). Böylece günümüz koşullarında eskiye oranla çok daha iyi kalite ve standartlarda betonarme binaların inşa edilmesi amaçlanmıştır.
Tablo 1. Ülkemizde son 60 yll içerisinde büyüklüğ̈̈ 6.5 ve üzeri olan depremler [7]

\begin{tabular}{ccc}
\hline Tarih & Yer & Büyüklük \\
\hline 06.10 .1964 & Manyas (Balıkesir) & 7.0 \\
19.08 .1966 & Varto (Muş) & 6.9 \\
22.07 .1967 & Mudurnu (Adapazarı) & 6.8 \\
03.09 .1968 & Bartın (Zonguldak) & 6.5 \\
28.03 .1970 & Alaşehir (Manisa) & 6.5 \\
28.03 .1970 & Gediz (Kütahya) & 7.2 \\
22.05 .1971 & Bingöl & 6.8 \\
06.09 .1975 & Lice (Diyarbakır) & 6.6 \\
30.10 .1983 & Erzurum - Kars & 6.9 \\
13.03 .1992 & Erzincan & 6.8 \\
17.08 .1999 & Gölcük (Kocaeli) & 7.8 \\
12.11 .1999 & Düzce & 7.5 \\
23.10 .2011 & Van & 7.2 \\
24.01 .2020 & Sivrice (Elazığ) & 6.6 \\
30.10 .2020 & Seferihisar (İzmir) & 6.6 \\
\hline
\end{tabular}

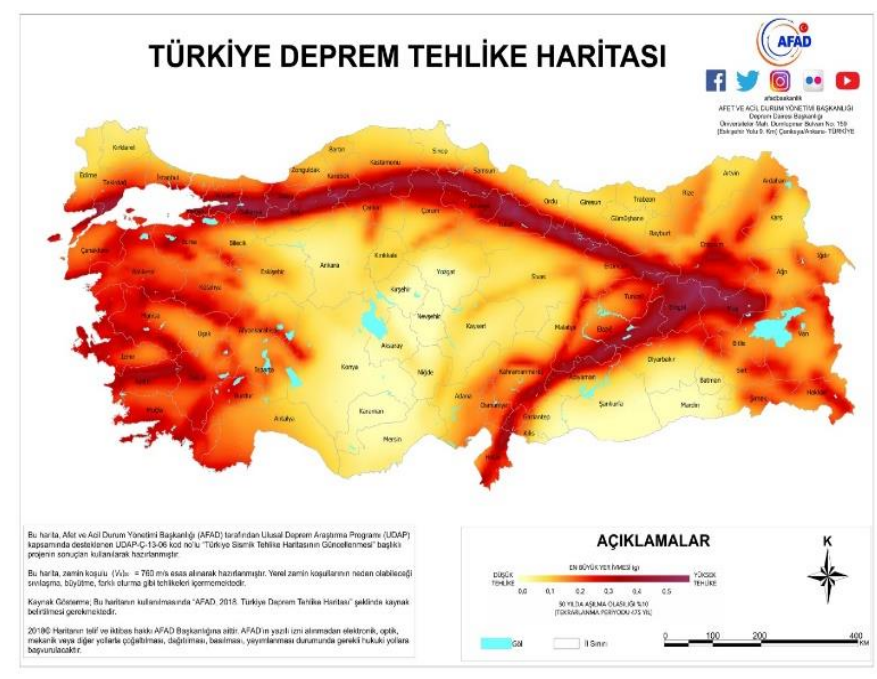

Şekil 1. Türkiye Deprem Tehlike Haritası [10]

Ülkemizin yaklaşık olarak 20 milyon yap1 stokunun bulunmaktadır. Bu yapı stokununda yaklaşık 5 milyonu 1999 y1lında meydana gelen Gölcük (Kocaeli) depreminden sonra yapılmıştır ve göreceli olarak daha iyi durumdadır [11]. Ancak gözden geçirilmesi gereken yaklaşı 15 milyon yap1 bulunmaktadır. $\mathrm{Bu} 15$ milyon yapının ise tahminen yarısının can ve mal güvenliği açısından riskli olduğu düşünülmektedir [1]. $\mathrm{Bu}$ durum da kentsel dönüşümü ülkemiz açısından kaçınılmaz hale getirmektedir.

Çeşitli araştırmacılar tarafından günümüze kadar yapılan çalışmalarda kentsel dönüşüm ile iş sağlığ 1 ve güvenliği farklı boyutlarıyla ele alınarak incelenmiştir [12] - [17]. Bu çalışma kapsamında 6 adet betonarme konut binasının deprem güvenliği TBDY (2018)'e göre incelenmiş ve bu binaların kentsel dönüşüm kapsamında yıkım işlemleri ülkemizde kullanılmakta olan iş sağlıği ve güvenliği standart ve yönetmeliklerine göre değerlendirilmiştir. 


\section{Materyal ve Metot}

\subsection{Binaların Deprem Güvenliği}

Mevcut betonarme binaların deprem güvenliği belirlenirken binaların deprem performans seviyesine göre karar verilmektedir. TBDY (2018)'de mevcut binaların deprem performansının belirlenmesi amacıyla doğrusal elastik ve doğrusal elastik olmayan hesap yöntemlerine yer verilmiştir. Doğrusal elastik yöntemlerde dayanım esaslı değerlendirme, doğrusal elastik olmayan yöntemlerde ise şekildeğiştirme esaslı değerlendirme yapılmaktadır. Bu çalışma kapsamında betonarme konut binalarının deprem performansını belirlemek için doğrusal elastik olmayan hesap yöntemlerinden "Tek Modlu İtme Yöntemi” kullanılmıștır.

TBDY (2018)'de binaların deprem performans1 belirlenirken taşıyıcı sistem elemanlarının hasar dağılımına ve miktarına göre karar verilmektedir. Sünek taşıyıcı sistem elemanlarının kesitleri için Sınırlı Hasar (SH), Kontrollü Hasar (KH) ve Göçme Öncesi Hasar (GÖ) olmak üzere üç farklı hasar sınırı ve bu hasar sınırlarına bağlı olarak da dört farklı hasar bölgesi tanımlanmıştır. Kesit hasarı SH'ye ulaşamayan elemanlar Sınırlı Hasar Bölgesi'nde, SH ve KH sınırları arasında kalan elemanlar Belirgin Hasar Bölgesi'nde, KH ve GÖ arasında kalan elemanlar İleri Hasar Bölgesi'nde ve GÖ'yü aşan elemanlar ise Göçme Bölgesi’nde yer almaktadır (Şekil 2).

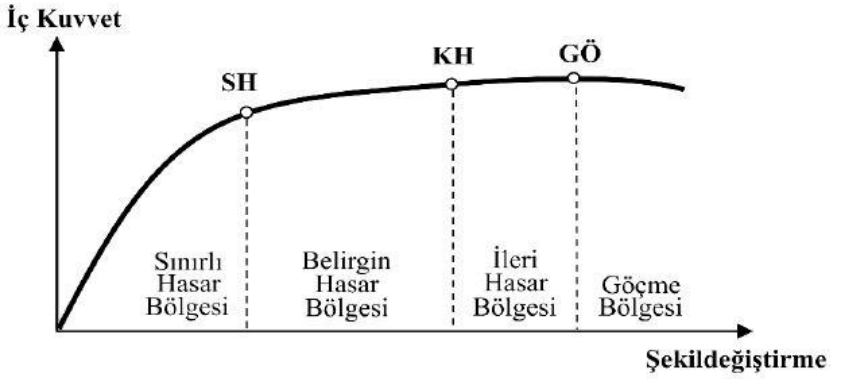

Şekil 2. Taşıyıcı sistem elemanlarının hasar sınırları ve bölgeleri [9]

TBDY (2018)'de binaların deprem performansı için Kesintisiz Kullanım (KK), Sınırlı Hasar (SH), Kontrollü Hasar $(\mathrm{KH})$ ve Göçmenin Önlenmesi (GÖ) olmak üzere dört farklı seviye verilmiştir. Göçmenin Önlenmesi performans seviyesinin sağlanmaması halinde bina Göçme Durumu'nda olmaktadır.

TBDY (2018)'e 50 yılda aşılma olasılığı \%10 olan DD-2 deprem seviyesi için betonarme konut binasının sağlaması gereken hedef performans seviyesi KH'dır ve gerekli koşullar aşağıda verilmiş̧ir.

$>$ Betonarme binanın herhangi bir katında ve her bir deprem doğrultusunda, kiriş elemanların en fazla $\% 35^{\prime} \mathrm{i}$ İleri Hasar Bölgesi'nde olabilir.

> İleri Hasar Bölgesi'nde olan düşey taşıyıcı elemanların, binanın her bir katında düşey taşıyıcı elemanlar tarafindan taşınan kesme kuvvetine katkıs1 \%20'nin altında, en üst katta ise en fazla $\% 40$ olmalıdır.

> Betonarme binanın herhangi bir katında alt ve üst uçlarının her ikisinde Belirgin Hasar Sınırını aşan düşey taşıyıcı elemanlar tarafindan taşınan kesme kuvvetleri, o kattaki düşey taşıyıcı elemanlar tarafından taşınan kesme kuvvetine oranı en fazla $\% 30$ olabilir.
Yapılan analizler sonucunda betonarme binanın TBDY (2018)'de belirtilen hedef performans seviyesini sağlamaması hâlinde güçlendirilmesi veya yıkımının gerçekleştirilmesi gerekmektedir.

\section{2. İş Sağlığı ve Güvenliği Açısından Yıkım İşlerinde Kullanılan Standart ve Yönetmelikler}

Kentsel dönüşüm kapsamında ülkemizde yaklaşı 7.5 milyon yapının yenilenmesi düşünülmektedir. $\mathrm{Bu}$ yüzden yapıların yıkım işlerinde kullanılan standart ve yönetmelikler oldukça önemli hale gelmektedir. Mevzuatlar incelendiğince, yıkım işlerine yardımcı olabilecek standart ve yönetmelikler sırasıyla incelenmiştir.

\subsubsection{Yapıların Tam ve Kısmi Yıkımı İçin Uygulama Kurallart (TS 13633)}

$\mathrm{Bu}$ standart [18] yapıların tam ve kısmi yıkım işleri için kullanılan yıkım teknikleri hakkında bilgi vermektedir. TS 13633 'de verilen yıkım teknikleri aşağıda sırasıyla verilmiştir.

$>$ El ile yıkım

$>$ Makine ile yıkım

> Uzaktan kontrol edilen makineler ve robotik cihazlar ile yıkım

> Kompakt makineler ile yıkım

> Yüksek erişimli makineler ile yıkım

> Kule ve diğer yüksek erişimli vinçler ile yıkım

$>$ İple çekerek yıkım

> Delme ve testere ile kesme ile yıkım

Dimyasal maddeler kullanılarak yıkım

> Patlayıcılar kullanarak yıkım

Sicak kesme ile yıkım

> Yüksek basınçlı su jeti kullanarak yıkım

> Metal tozu kullanarak kesim

Yukarıda verilen 13 adet yapı yıkım yönteminden genel olarak bahsedilmiş ve yıkım yöntemlerinin uygulama esaslarından, yıkım esnasında uyulması gereken kurallardan, alınması gereken önlemlerden, vb. birçok önemli konuda detaylı bilgiye yer verilmemiştir.

\subsubsection{Hafriyat Toprağı, İnşaat ve Yıkıntı Atıklarının Kontrolü Yönetmeliği}

$\mathrm{Bu}$ Yönetmelikte [19] hafriyat toprağı, inşaat ve yıkıntı atıklarının yönetimi ilkelerinden, bu atıkları üretenlerin yükümlülüklerinden, inşaat ile yıkıntı atıklarının toplanarak taşınmasından, yıkım faaliyetleri için alınması gerekli izinlerden, yıkım işlemlerinden, tehlikeli atıkların toplanması ve bertarafından, bu atıkların taşınması esnasında alınması gerekli önlemlerden, vb. konulardan bahsedilmiştir. Yıkıntı atıkları ile ilgili uyulması gereken kurallar aşağıda verilmiştir.

> Yıkıntı atıkları ile hafriyat toprağının birbiriyle karıştııılmaması, atıkların direkt olarak kaynağında ayrıştırılması ve seçici yıkım yapılması gerekmektedir.

> Yıkımı yapılan yapılarda geri kazanılabilir malzemelerin ayrıştırılması gerekmektedir. Bu kapsamda 
dolap, pencere, kapı, duvar ile taban kaplamaları, yalıtım, vb. inşaat malzemeleri ile tehlikeli atıkların yıkımı yapılan yapılardan ayrı toplanmalıdır. Y1kımın hidrolik ekipmanlı iş makineleri ile yapılması halinde kolon, kiriş, vb. betonarme elemanlar parçalanmalıdır.

Asbestli malzemelerin kullanıldığı binaların yıkımında çalışanların sağlığını ve güvenliğini korumak için "Asbestle Çalışmalarda Sağlık ve Güvenlik Önlemleri Hakkında Yönetmelik" kurallarına uyulması gerekmektedir.

$>$ Yıkım işlemleri esnasında toz emisyonlarının asgariye indirilmesi, görüntü kirliliğinin önlenmesi ve gerekli emniyet önlemlerinin alınması için yıkımı yapılan binaların cephelerine tutucu ve yırtılmaz özelliği olan file vb. malzeme kullanılarak koruma altına alınmalıdır.

> Y1kıntı atıklarında asbest, boya, floresan, asit, cıva, vb. tehlikeli atıklar bulunması halinde diğer atıklardan ayrıştırılarak toplanmalıdır.

\subsubsection{Yapı İşlerinde İşS Sağllğ̆ ve Güvenliği Yönetmeliği}

$\mathrm{Bu}$ Yönetmelikte [20] yapı işlerinde alınması gereken asgari iş sağlığı ve güvenliği önlemleri ile yapı işlerinden bahsedilmiştir. Yıkım işleri, yapı işlerinin içerisinde yer almaktadır. Yıkım işlerinde uyulması gereken kurallar aşağıda verilmiştir.

\begin{abstract}
$>$ Yıkımdan önce yapı içerisinde ve etrafındaki elektrik, su ve doğalgaz bağlantıları kesilerek yıkım işlemi yapılacak kısmın çevresinde güvenlik alanı oluşturulur ve gerekli olan tedbirler alınır.
\end{abstract}

$>$ Yıkım sırasında en uygun çalışma yöntemleri ile ekipmanlar kullanılarak gerekli olan tedbirler alınır.

$>$ Çalışmalar, ehil kişinin veya kişilerin gözetimi altında planlanarak yapılır.

$>$ Y 1 kım sirasında tozun kalkmaması ve yıkıma ait malzeme ve molozların yıkım ortamından güvenli bir şekilde uzaklaştırılması için gerekli olan tedbirler alınır.

\subsubsection{Asbestle Çalışmalarda Sağlık ve Güvenlik Önlemleri Hakkında Yönetmelik}

$\mathrm{Bu}$ Yönetmelikte [21] asbestin sökümü, yıkımı, tamiri, bakımı ve uzaklaştırılması işlerinde çalışanların asbest tozuna maruziyetlerinin önlenerek korunması için alınması gereken önlemlerden ve asbest sınır değerlerinden bahsedilmiştir. Asbestle çalışmalarda uyulması gereken kurallar aşağıda verilmiştir.

> Bakım, tamir, söküm, yıkım ve uzaklaştırma işlerinden önce asbest içerebilecek malzeme ve yerlerde inceleme yapılarak gerekli tedbirler alınır.

> İşverenler, asbest içerebilecek malzemelerin sökümü, yıkımı, tamiri, bakımı ve uzaklaştırılması işlerini asbest söküm uzmanı gözetiminde asbest söküm çalışanlarınca yapılmasını sağlar.

Bakım, tamir, söküm, yıkım ve uzaklaştırma işlerinde havadaki asbest konsantrasyonunun sekiz saatlik zaman ağırlıklı ortalama değerinin $0.1 \quad$ lif $/ \mathrm{cm}^{3}$ değerini aşılabileceği durumlarda çalışanların uygun solunum sistemi koruyucularını ve diğer kişisel koruyucu donanımları kullanması sağlanır. İlgili yerlere gerekli işaretlemeler yapılarak uyarı levhaları konulur. Asbestli malzemeden çıkan tozun, çalışılan alan dışına yayılmasını önlemek için gerekli önlemler alınır ve çalışılan alana görevliler haricindeki çalışanların girmesi önlenir.

Asbest malzemesi yüksek derecede 1sıya, aşınmaya ve paslanmaya karşı dayanıklı olması, ses ve 1sı yalıtımının iyi olması, elektrik geçirgenliğinin az olması, çimento vb. malzemeler ile kullanılabilmesi özellikleri nedeniyle inşaat ve sanayi sektöründe kullanılmıştır. Ülkemizde asbest malzemesinin kullanımına 2003 yılında sınırlama getirilmiş ve 2010 yılında ise kullanımı yasaklanmıştır. 1980 yılından önce yapılan binaların birçok yerinde asbestin yoğun bir şekilde kullanıldığ 1 düşünülmektedir. Bina içerisinde en yaygın olarak kullanıldığı yerler Şekil 3 ’te gösterilmiştir.

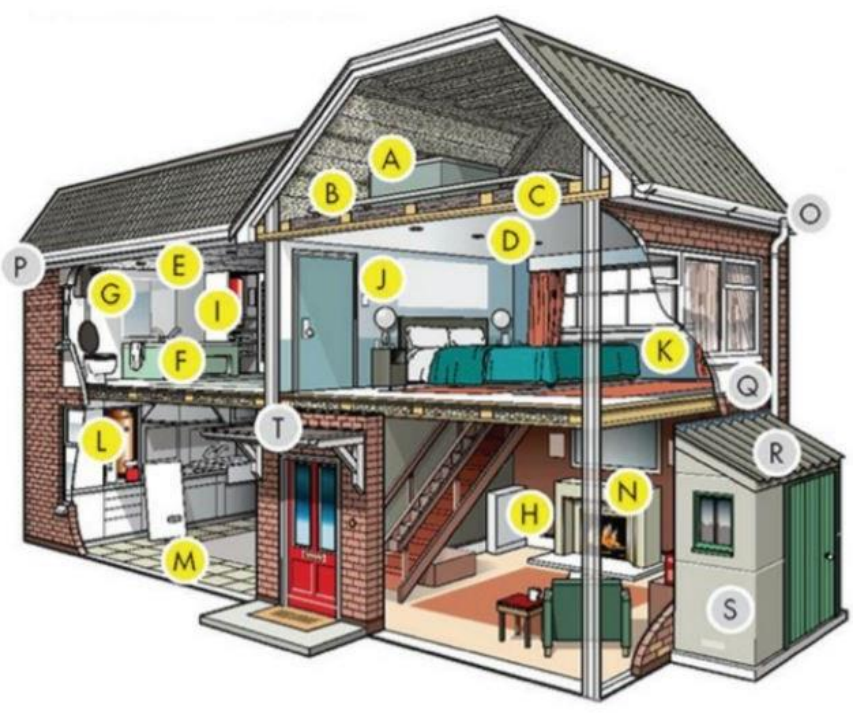

Şekil 3. Binalarda asbestin kullanıldiğg yerler [22]

Şekil 3 'te verilen bina incelendiğinde asbestin bina içerisinde en yaygın olarak kullanıldığ 1 yerler aşağıda sırasıyla verilmiştir.
A. Su deposu
B. Boru izolasyonları
C. Çatı izolasyonu
D. Duvar kaplamaları
E. Tavan döşemeleri
F. Küvet
G. Klozet

H. Sigorta kutuları ve prizler

I. Püskürtme izolasyon malzemeleri

J. Bölme duvarlar

K. İç pencere paneli

L. Kazan ve isitici

M. Marley ve yer kaplaması

N. Şönine

O. Yağmur olukları ve borular

P. Saçak malzemeleri

Q. Yalıtım levhalı dış pencere paneli 
R. Eternit

S. Dış cephe kaplamaları

T. Çatı kaplamaları

\subsection{5. Çevresel Gürülttünün Değerlendirilmesi ve Yönetimi Yönetmeliği}

$\mathrm{Bu}$ Yönetmelikte [23] insanların maruz kaldığı çevresel gürültüler ve titreşime yönelik esasları ve usulleri kapsamaktadır. Bu kapsamda binalar için yapım, onarım ve yıkım işlerinin yapıldı ğı şantiyelerden çevreye yayılan gürültü seviyesi $75 \mathrm{dBA}$ sınır değerini aşamaz. İnşaat makinelerinden kaynaklanan zemin titreşimlerin seviyesi yerleşim yerlerinde sürekli titreşim durumunda $5 \mathrm{~mm} / \mathrm{s}$, kesikli titreşim durumunda ise $10 \mathrm{~mm} / \mathrm{s}$ titreşim hızı değerlerini aşamaz.

\subsubsection{Atık Yönetimi Yönetmeliği}

Bu Yönetmelikte [24] atıkların insan sağlığına ve çevreye zarar vermeden yönetimini sağlayarak atık oluşumunun azaltılmas1/önlenmesi ve geri dönüşümünün yapılarak doğal kaynakların kullanımının azaltılmasından bahsedilmiştir. Yönetmelik içerisinde inşaat ve yıkıntı atıklarının detaylı olarak listesi verilmiştir. $\mathrm{Bu}$ listede atıkların tehlikelilik durumu (kesin/muhtemel) ve tehlikelilik özelliklerine yönelik çalışma yapılıp/yapılmaması hakkında bilgi verilmektedir.

\subsection{7. Çevresel Gürülttünün Değerlendirilmesi ve Yönetimi Yönetmeliği}

Bu Yönetmelikte [25] atıkların düzenli depolanması yoluyla bertaraf edilmesi halinde oluşması ihtimal sızıntı sularının ve depo gazlarının hava, toprak, yüzeysel ve yeraltı suları üzerindeki etkilerini asgari seviyeye düşürerek çevre kirliliğinin önlenmesi amaçlanmıştır.

Fiziksel, kimyasal ve biyolojik olarak herhangi bir değişime uğramayan, çözünmeyen, yanmayan veya temas halinde olduğu maddeleri insan hayatına ve çevreye zarar verecek seviyede etkilemeyen, sızıntı yeteneği ve ekotoksisitesi önemsiz seviyede olan, yeraltı ve yüzeysel su kirliliği tehlikesi oluşturmayan atıklar inert atık olarak tanımlanmaktadır. Bu tanıma uyan seramik, tuğla, kiremit ve betondan oluşan karışımların atıkları, inert atı depolama tesislerine herhangi bir teste tabi tutulmaksızın kabul edilirler. İnşaat atıkları, asbest içermesi durumunda test edilmeden ikinci sinıf depolama tesislerinde depolanabilirler.

\section{Araştırma Sonuçları ve Tartışma}

Bu çalışmada Isparta ilinde 1970 yılında inşa edilmiş olan 6 adet betonarme tek tip konut binasının deprem performans analizleri gerçekleştirilmiş ve bu binaların kentsel dönüşüm kapsamında yıkım işlemi ülkemizde kullanılmakta olan iş sağlığ ve güvenliği standart ve yönetmeliklerine göre incelenmiştir.

\subsection{Binaların Deprem Performans Analizleri}

Isparta ilinde 1970 y1lında 4 katlı olarak inşa edilmiş çerçeve taşıyıcı sistemine sahip 6 adet betonarme tek tip konut binasının deprem performans analizleri Sta4-CAD [26] programı kullanılarak DD-2 deprem düzeyi (50 yılda aşılma olasılığı \%10) için yapılmıştır.

Binalara ait sabit yapısal parametrelerden donatı sınıfi S220, kat yüksekliği 2.75 metre, toplam bina alanı $671 \mathrm{~m} 2$, bina ağırlığı yaklaşık $7350 \mathrm{kN}$, zemin sınıfı ZD, kısa periyot ve 1 saniye periyot için tasarım spektral ivme katsayısı sırasıyla 0.895 ve 0.384'tür. Binaların beton dayanımı (fcm) değerleri ile yapılan analizler sonucunda elde edilen binaların $x$ ve $y$ yönlerine ait periyot değerleri ( $\mathrm{Tx}$, Ty), riskli bulunan kat adet sayıları ve bina performans seviyeleri Tablo 2'de verilmiştir. Sta4-CAD programında oluşturulan bina modellerine kat planı Şekil 4'te ve 3 boyutlu modele ait görüntüsü Şekil 5'te sunulmuştur.

Tablo 2. Binaların analiz sonuçları

\begin{tabular}{cccccc}
\hline $\begin{array}{c}\text { Bina } \\
\text { No }\end{array}$ & $\begin{array}{c}\mathbf{f}_{\mathbf{c m}} \\
(\mathbf{M P a})\end{array}$ & $\begin{array}{c}\mathbf{T}_{\mathbf{x}} \\
(\mathbf{s n})\end{array}$ & $\begin{array}{c}\mathbf{T}_{\mathbf{y}} \\
(\mathbf{s n})\end{array}$ & $\begin{array}{c}\text { Riskli } \\
\text { Bulunan } \\
\text { Kat Adedi }\end{array}$ & $\begin{array}{c}\text { Performans } \\
\text { Seviyesi }\end{array}$ \\
\hline 1 & 18.14 & 0.87 & 0.65 & 4 & Göçme \\
2 & 16.98 & 0.89 & 0.67 & 2 & Göçme \\
3 & 18.16 & 0.87 & 0.65 & 3 & Göçme \\
4 & 16.28 & 0.90 & 0.67 & 4 & Göçme \\
5 & 18.37 & 0.87 & 0.65 & 3 & Göçme \\
6 & 18.25 & 0.89 & 0.66 & 3 & Göçme \\
\hline
\end{tabular}

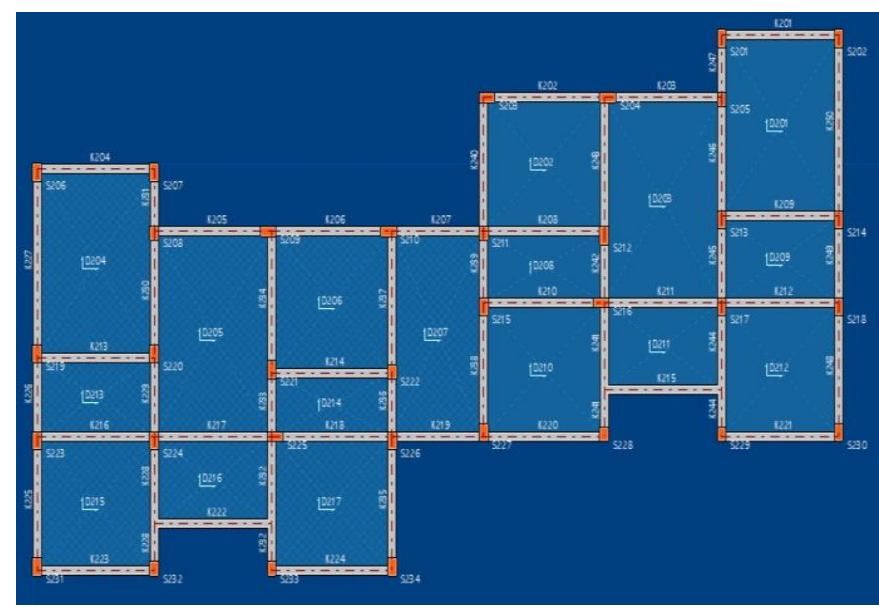

Şekil 4. Binaların kat planı

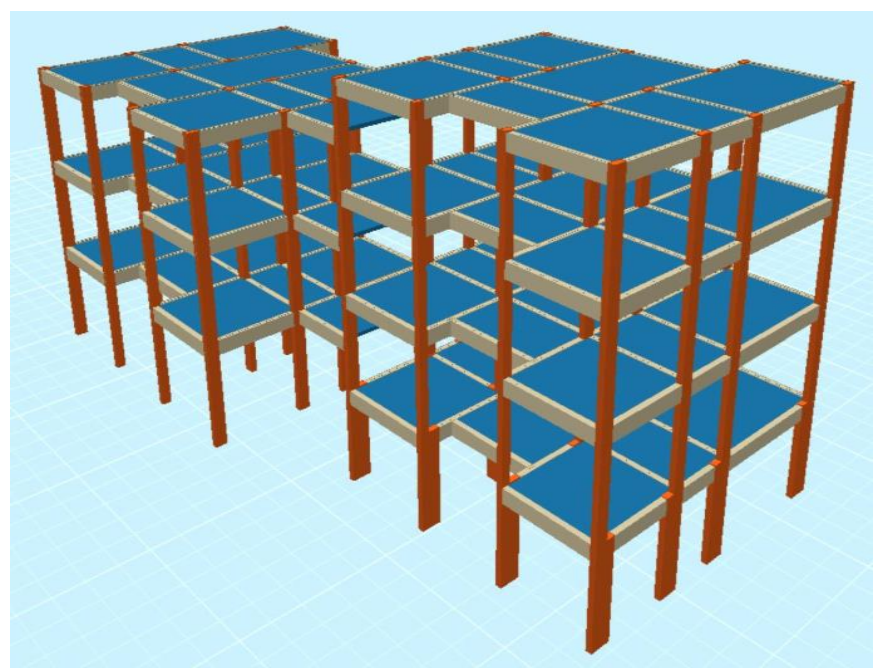

Şekil 5. Binaların 3 boyutlu taşıyıcı sistem modeli

Yapılan analizler ve değerlendirme sonucunda betonarme konut binalarının TBDY (2018)'de verilen hedef performans seviyesi olan KH'yı sağlamadığı ve riskli bina oldukları görülmüştür. Bunun sonucunda binaların yıkılmasına karar verilmiştir. 


\subsection{Binaların Yıkım İşlemleri}

Yıkılmasına karar verilen binaların yıkım işlemine geçilmeden önce binalar boşaltılarak elektrik, su ve doğalgaz bağlantıları kesilmiştir. Yıkım işlemi gerçekleştirilecek binaların parsele yerleşimi Şekil 6'da verilmiştir.

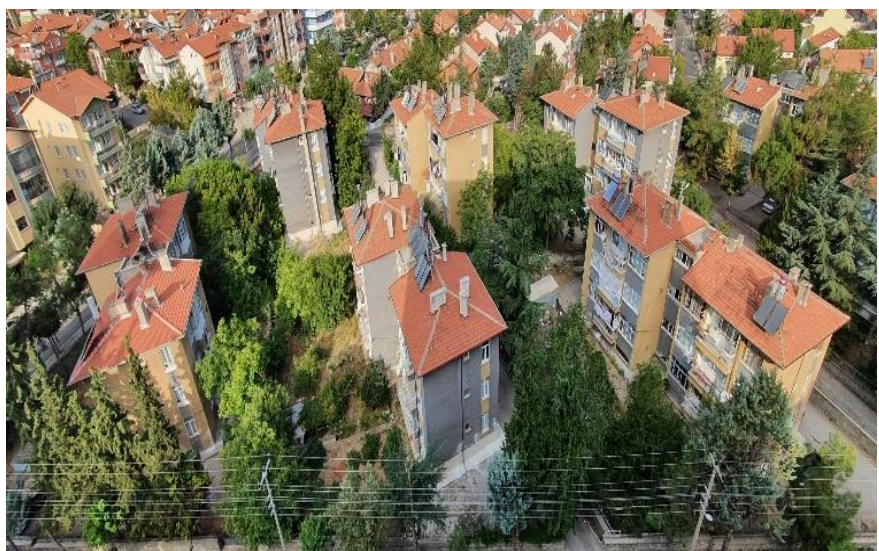

Şekil 6. Yıkımı işlemi gerçekleştirilecek binalar

Yıkım işleminde atıkları kaynağında ayrıştırarak ülke ekonomisine tekrar kazandırmak amacıyla seçici yıkım tekniği uygulanmıştır. $\mathrm{Bu}$ kapsamda geri dönüşümü mümkün olan batarya, eviye, lavabo, küvet, kapı, pencere, dolap, cam, mermer, ahşap, metal, çelik, alüminyum, bakır, elektrik kabloları, atık su boruları, doğalgaz tesisatları, balkon ve merdiven korkuluk demirleri, çatı keresteleri, kiremit, bordür ve parke taşı vb. malzemeler seçici yıkım yapılarak yıkım alanından taşınmıştır. Seçici yıkım yöntemine ait bazı görüntülere Şekil 7'de yer verilmiştir.

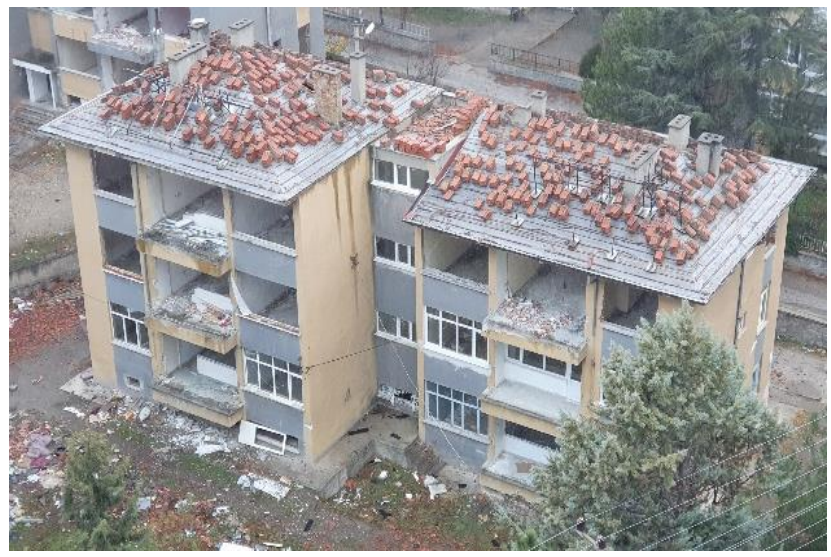

(a) Çatı kaplamasının sökülmesi

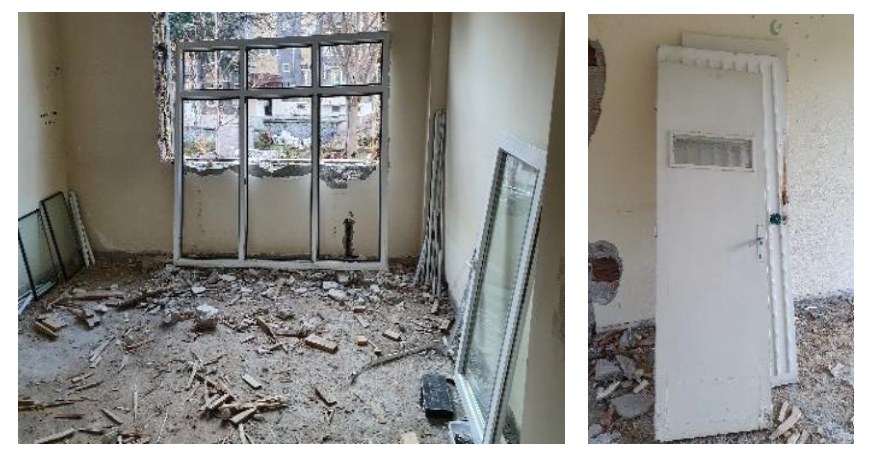

(b) Kapı ve pencerelerin sökülmesi

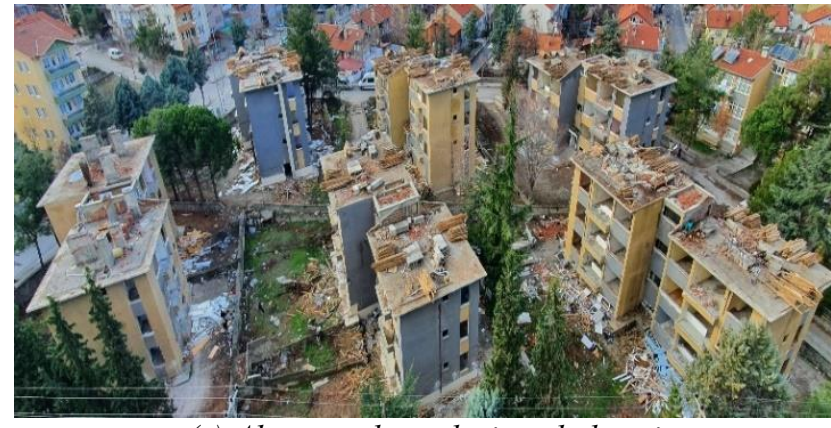

(c) Ahşap malzemelerin sökülmesi

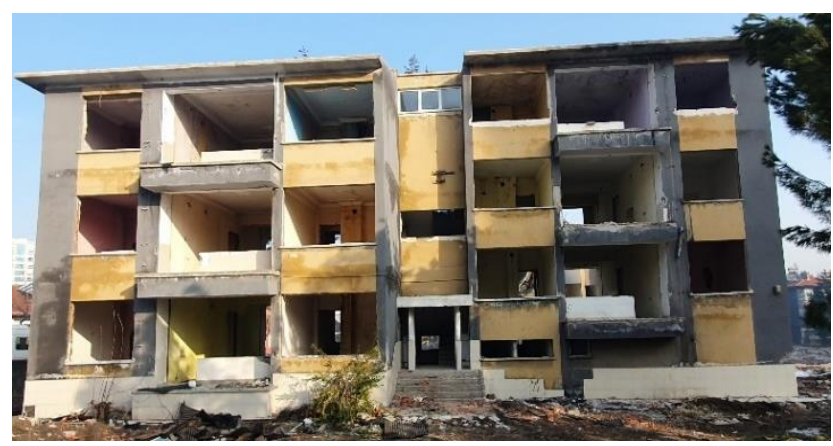

(d) Seçici yıkım işlemi tamamlanmış bina

Şekil 7. Binalarda seçici yıkım yapılması

Seçici yıkım yöntemiyle malzemelerin söküm işlemi tamamlandıktan sonra binaların taşıyıcı sistem elemanları (kiriş, kolon ve döşeme), tuğla duvarlar ve sslak alan kaplamaları kalmıştır. Binaların geriye kalan kısımlarının yıkımı makine ile yıkım tekniği kullanılarak yapılmıştır. Bu kapsamda ekskavatör denilen iş makineleri kullanılmıştır (Şekil 8). Yıkım esnasında betonarme elemanlardaki hurda demirler ve ortaya çıkan metaller ayrıştırılmıştır (Şekil 9). Binaların yıkım işlemi sırasında ortaya çıkan atıklar yıkım alanından uzaklaştırılıp, temizlenmiştir (Şekil 10).

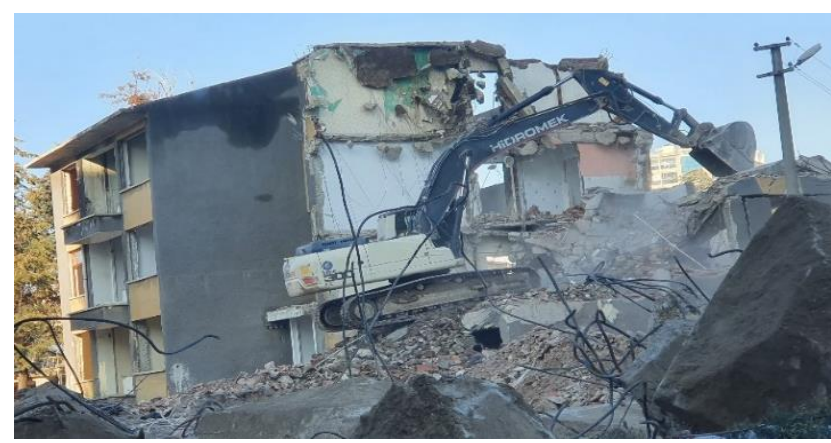

(a) Yıkımı yapılan bina

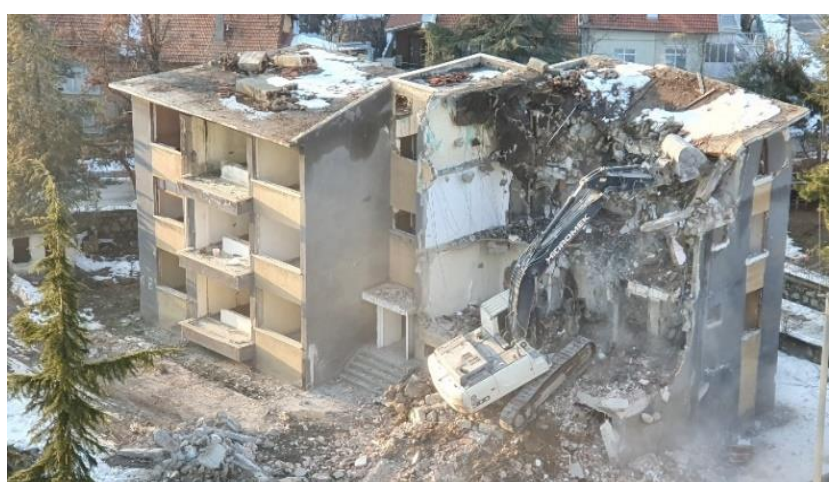

(b) Yıkımı devam eden bina

Şekil 8. Binaların ekskavatör kullanılarak yıkılması 


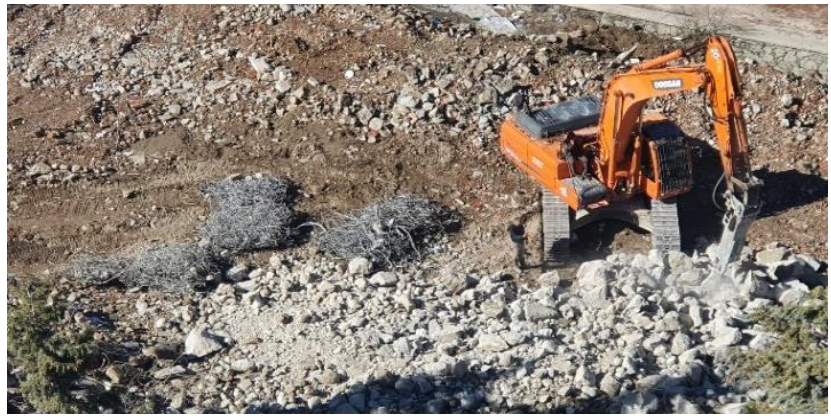

Şekil 9. Yıkım esnasında çıkan hurda demirin ayrıştırılması

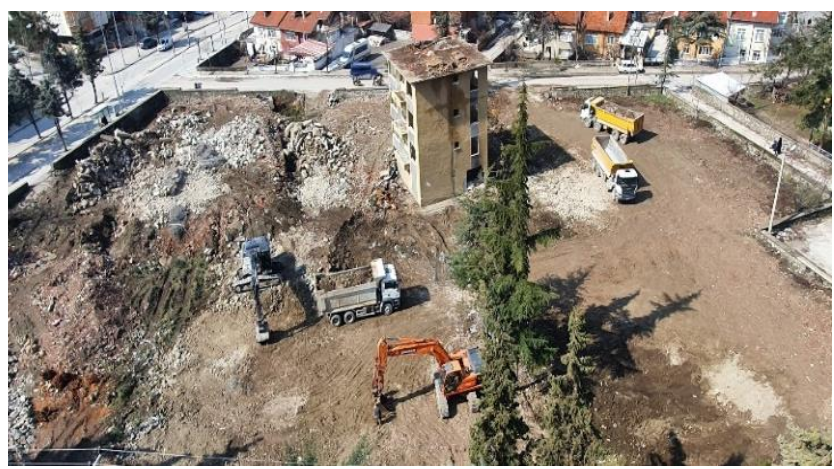

Şekil 10. Yıkıntı atıklarının yıkım alanından uzaklaştırılması

\section{Sonuç}

$\mathrm{Bu}$ çalışma kapsamında Isparta ilinde 1970 yılında inşa edilmiş 6 adet betonarme tek tip konut binasının deprem performans analizleri Sta4-CAD programında yapılmış ve deprem güvenlikleri yetersiz bulunmuştur. Bunun sonucunda binaların kentsel dönüşüm kapsamında yıkılmasına karar verilmiştir. Binaların yıkım işlemleri aşamasında ülkemizde kullanılmakta olan standart ve yönetmelikler, iş sağlı̆̆ ve güvenliği açısından ele alınarak incelenmiştir. Yapılan çalışma sonucunda elde edilen sonuçlar aşağıda verilmiştir.

Yapıların yıkım işlemlerini geniş kapsamlı olarak ele alan, yıkım tekniklerini detaylı olarak inceleyen, yıkım işlemlerinde uygulanması gereken kural ve yöntemleri net ve kesin bir ifade ile belirten bir standart veya yönetmelik bulunmadığ görülmüştür. Ancak, yapılarda kullanılan yıkım metotları ile ilgili sınırlı içeriğe sahip Yapıların Tam ve Kısmi Yıkımı İçin Uygulama Kuralları (TS 13633) bulunmaktadır.

Yıkım işlemlerine başlanılmadan önce yıkım alanında ve çevresinde gerekli olan güvenlik önlemleri alınmalıdır. Bu durum yetkililer tarafindan da denetlenmelidir.

Yıkım işlerinde iş kazalarının önüne geçebilmek için yıkım planı ile iş sağlı̆̆ ve güvenliği planları hazırlanarak uygulanması sağlanmalıdır.

Y1kılması planlanan binalarda tehlikeli atıkların varlığ yıkılmadan önce muhakkak belirlenmelidir. Tehlikeli atıkların bulunması halinde bu atıkların türü ve miktarı belirlenerek söküm ve yıkım işlemlerinde uzman kişilerin gözetiminde gerçekleştirilmelidir. Yıkım işleminden sonra bu atıklar için uygun olan depolama işlemine karar verilerek atık yönetimi sürecine gerekli özen gösterilmelidir.

Yıkım işlemleri esnasında oluşan gürültü, toz ve titreşimin ölçümleri yapılarak insan sağlığına ve çevreye zarar verilmeden yıkıımın yapılması sağlanmalıdır.
Yıkım işlerinde en tehlikeli durumun yıkım alanında asbestli malzeme bulunması olarak düşünülebilir. $\mathrm{Bu}$ yüzden yıkım işlerine başlanılmadan önce uzman kişiler tarafından denetim yapılarak asbest varlığının olup/olmadığı ile ilgili rapor hazırlanmasında yarar vardır.

Mevcut standart veya yönetmeliklerin, günümüz ihtiyaçlarına göre detaylı olarak ele alınmasında ve revize edilmesinde yarar vardir.

\section{Kaynakça}

[1] RAİUK. (2018). Riskli Alan İlanı ve Uygulama Kılavuzu. Çevre ve Şehircilik Bakanlığı, Ankara.

[2] İnel, M., Bilgin, H. \& Özmen, H., (2006). Mevcut Kamu Yapılarının Performans Değerlendirmesi. Türkiye Mühendislik Haberleri, 444-445, 64-71.

[3] İnel, M., Bilgin, H. \& Özmen, H., (2007). Okul Binalarının Yeni Deprem Yönetmeliğine Göre Değerlendirilmesi. Altıncı Ulusal Deprem Mühendisliği Konferansı, 257-267, İstanbul.

[4] Gündoğay, A. \& Tekeli, H., (2018). Atölye binalarının deprem performansinı etkileyen bazı parametrelerin incelenmesi. 6th International Symposium on Innovative Technologies in Engineering and Science, 929-938, Antalya.

[5] Gündoğay, A., Ulutaş, H., \& Tekeli, H. (2019). Mevcut atölye binalarının deprem güvenliğinin incelenmesi. Dicle Üniversitesi Mühendislik Fakültesi Mühendislik Dergisi, 10(2), 755-768. DOI: $10.24012 /$ dumf.432136

[6] Sar1, O. \& Ulutaş, H. (2021). Mevcut konut türü betonarme bir binanın deprem güvenliğinin incelenmesi. Gümüşhane Üniversitesi Fen Bilimleri Dergisi, 11(4), 1129-1144. DOI: 10.17714/gumusfenbil.906844

[7] URL-1. (2017). Deprem Bilgileri-Büyük Depremler. Erişim: http://www.koeri.boun.edu.tr/sismo/2/deprembilgileri/buyuk-depremler/

[8] DBYBHY. (2007). Deprem Bölgelerinde Yapilacak Binalar Hakkında Yönetmelik. Bayındırlık ve İskân Bakanlığı, Ankara.

[9] TBDY. (2018). Türkiye Bina Deprem Yönetmeliği. Afet ve Acil Durum Yönetimi Başkanlığı, Ankara.

[10] AFAD. (2018). Türkiye Deprem Tehlike Haritası. Afet ve Acil Durum Yönetimi Başkanlığı, Ankara.

[11] URL-2. (2017). Türkiye'nin ortalama 20 milyon yap1 stoku var. Erişim: https://emlakkulisi.com/turkiyenin-ortalama20-milyon-yapi-stoku-var/521868

[12] Öcal, C. \& İnce, H. H. (2012). Türkiye'de Mevcut Yap1 Stoğu ve Kentsel Dönüşüm. Uluslararası Teknolojik Bilimler Dergisi, 4(2), 89-95.

[13] Akboğa-kale, Ö., Gürcanlı, G. E. \& Baradan, S. (2017). Kentsel dönüşüm sürecinde asbest maruziyeti ve korunma yöntemleri. Pamukkale Üniversitesi Mühendislik Bilimleri Dergisi, 23 (6), 694-706.

[14] Poyraz, Ü. (2016). TÜRKIYE İNŞAAT YIKINTI ATIK YÖNETIM SISTEMININ GELIŞTİIILMESİ. Gazi Üniversitesi, Fen Bilimleri Enstitüsü, Yüksek Lisans Tezi, Ankara.

[15] Yönez, E. (2017). 6306 Sayılı Kanuna Göre Riskli Bir Binanın Dönüşüm Süreci ve Karşılaşılan Sorunlar: Bir İlçe Belediyesi Örneği," İstanbul Teknik Üniversitesi, Fen Bilimleri Enstitüsü, Yüksek Lisans Tezi, İstanbul. 
[16] Salgın, B. \& Coşgun, N. (2018). Kentsel Dönüşüm Uygulamalarında Yapısal Atik Sorunu ve Çözüme Yönelik Öneriler: Kayseri Örneği. Niğde Ömer Halisdemir Üniversitesi Mühendislik Bilimleri Dergisi, 7(1), 465-476. DOI: $10.28948 /$ ngumuh.387388

[17] Özel, H. (2018). Kentsel Dönüşümde Y1kım Uygulamalarının İş Sağlığı Ve Güvenliği Açısından Analizi Kocaeli Örneği. Hasan Kalyoncu Üniversitesi Fen Bilimleri Enstitüsü, Yüksek Lisans Tezi, Gaziantep.

[18] TS 13633. (2017). Yapıların Tam ve Kısmi Yıkımı İçin Uygulama Kuralları. Türk Standardları Enstitüsü, Ankara.

[19] HTIYYAKY. (2004). Hafriyat Toprağı, İnşaat ve Yıkıntı Atıklarının Kontrolü Yönetmeliği. Çevre ve Orman Bakanlığı, Ankara.

[20] YİISGY (2013). Yapı Işslerinde Işs Să̆lı̆̆ ve Güvenliği Yönetmeliği. Çalışma ve Sosyal Güvenlik Bakanlığı, Ankara.
[21] AÇSGÖHY. (2013). Asbestle Çalışmalarda Sağlık ve Güvenlik Önlemleri Hakkında Yönetmelik. Çalışma ve Sosyal Güvenlik Bakanlığı, Ankara.

[22] TMMOB, (2018). İstanbul Asbest Raporu. Türk Mühendis ve Mimar Odaları Birliği İstanbul İl Koordinasyon Kurulu, 6-31.

[23] ÇGDYY. (2010). Çevresel Gürültünün Değerlendirilmesi ve Yönetimi Yönetmeliği. Çevre ve Orman Bakanlığı, Ankara.

[24] AYY. (2015). Atık Yönetimi Yönetmeliği. Çevre ve Şehircilik Bakanlığı, Ankara.

[25] ADDDY. 2010. Atıkların Düzenli Depolanmasına Dair Yönetmelik. Çevre ve Orman Bakanlığı, Ankara.

[26] Sta4-CAD. (2021). Structural Analysis for Computer Aided Design. v14, İstanbul, Türkiye. 